\title{
"Pseudo-Events" as a Form of Public Relations in the Postmodern World: A Case Study PinkorBlack Night*
}

\author{
Postmodern Dönemde Bir Halkla Illişkiler Aracı olarak "Pseudo-Event": \\ PinkorBlack Gecesi Vaka Analizi
}

\author{
Res. Asst. Beris Artan Özoran
}

Başvuru Tarihi: 18.03.2017

Kabul Tarihi: 19.03.2018

\begin{abstract}
When it comes to postmodernity, confusion arises. The main reason for this confusion lies under the main differentiation between postmodern sociology and sociology of postmodernism. This difference affects many fields and public relations is one of them. In this study, I follow the path of postmodern public relations which deals with postmodernism as an era not an epistemology. Therefore in this article, the transformation and new characteristics of public relations in the postmodern era was discussed. The main claim of this article is that in the postmodern era, public relations can be used a mean for enchantment. Also, pseudo-events turned into an essential tool for public relations since organizations need to be more visible in this era in which images turned out to be more vital than realities. PinkorBlack night arranged by Unilever was analyzed as a pseudo event. Event's videos, written material and social media accounts were examined by using descriptive analysis. As a result, it is seen that Magnum used this pseudo-event to create both visual simulation and a "dialogue" simulation not just for raising awareness about its new products but also strengthen the image of hyper-real "Magnum Woman". With this event Magnum positioned not just like an ice-cream, but also sophistication, energy, pleasure and beauty.
\end{abstract}

Keywords: Postmodernity, Public Relations, Pseudoevent

\section{Öz}

Postmoderniteden bahsedildiğinde bir kafa karışıklığı yaşandiğı görülmektedir. Bu karışıkliğın temel nedeni "postmodern sosyoloji" ile "postmodernizmin sosyolojisi" arasındaki farkta yatmaktadır. Bu fark diğer alanları olduğu gibi halkla ilişkileri de etkilemektedir. Bu çalışmada, postmodern sosyoloji yolundan ilerlenmiş; postmodernite bir epistemoloji olarak değil, bir dönem olarak ele alınmıştır. Bu nedenle makalede, halkla ilişkilerin postmodern dönemde yaşadiğı dönüşüm ve yeni özellikleri tartışılmıştır. Makalenin temel amacı, postmodern dönemde halkla ilişkiler bir "büyülüme aracı" olarak işlev görebildiğini tartışmaktır. Pseudoevent de imajlarm gerçeklerden daha önemli hale geldiği bir dönemde, daha görünür olmak isteyen örgütler için önemli bir araçtır. Makalede Unilever tarafindan düzenlenen PinkorBlack gecesi bir pseudo eveny olarak ele alınmıştır. Etkinliğin videolaro, yazılı materyaller ve sosyal medya hesapları betimsel analiz yoluyla incelenmiştir. Sonuç olarak, Magnum'un bu pseudo-event'i hem göresel hem de diyalog simülasyonu olarak kullandığı görülmüştür. Bu etkinlik sadece yeni ürünleri ile ilgili farkındalı̆̆ artırmak için değil, aynı zamanda hipergerçek Magnum kadının imajın güçlendirmek için de kullanılmıştır. Entelektüellik, enerji, haz ve güzellik gibi değerler vurgulanmıştır.

Anahtar Kelimler: Postmodernite, Halkla İlişkiler, Pseudo-event

Res. Asst. Beris Artan Özoran, Anakara University Faculty of Communication, beris87@hotmail.com

* This paper was presented in PR6 Meeting, Barcelona. 


\section{Introduction}

Public relations literature generally exploits from communication studies. Because of mainstream studies' dominance in the communication field, public relations likewise dominated by the mainstream approach. Although there many different paradigms in the field, the most dominant one saw public relations as a "management function", evaluate public relations from a management point of view. At the same time, most of the studies in the field performed within the framework of positivist social science. Dance states that the reason for this is the society's need for measurement, generalization, providing norms to be used in policy production (trans. Hınçal, 2011, pp. 202). Turkey isn't an exception about this issue. In their research on doctorate thesis and articles on public relations, Yamanoğlu and Özdemir (2009, pp. 28) observed that alternative critical definition efforts are almost ignored. In the majority of the studies public relations is addressed as a tool to support existing systems, and make it work. This generates a one-way perception about the field.

However, one can say that alternative perceptions about public relations gained acceleration in the last decade. According to Gower (2009, pp. 31-32), public relations research is at crossroads. The assumptions of mainstream research are under challenge by postmodernist, critical/cultural theorists and others. They propose new approaches and theories for the development of the public relations field. Similarly, Dühring (2015, pp. 6) states that critical voices also began to be heard against traditionally strong, positivist and functional approach. Public relations researches were criticized for ignoring new trends such as chaos, complexity, diversity and postmodernism. Alternative approaches began to develop new theoretical paradigms that open up the improvement of the field. Dühring (2015, pp. 7) defined these approaches as "turn". Even it is delayed, these new studies in public relations have begun to capture "turns" in social sciences. There is no homogeneity among these different approaches, but they all agree on criticizing the Grunig paradigm. Interpretive turn, cultural turn and postmodern turn are only some of them. Consequently, one can say that there is a requirement for alternative studies in the field, especially in Turkey. Because of that, this article is an initiative to link "postmodern" with public relations field.
One can say that there are many intersections and research fields between the concepts of "postmodern/ postmodernism/postmodernity" and "public relations". Some can focus on organization, public; some can front methodology, culture or language. The aim of this article is to evaluate public relations implementations in the postmodern era.

The concept of "postmodernism" is very controversial. When Judith Butler said "I don't know what postmodernism means", she speaks not just for most of the postmodernists but many of the modernists (Ritzer, 1996, pp. 5). One of the main reasons of the uncertainty and the confusion about "postmodernism" is that the postmodern social science theory and the periodization named "postmodernity" are intermingled and occasionally used in place of each other. Bauman (1998, pp. 803-804) indicated this difference as naming them "postmodern sociology" and "sociology of postmodernism". According to him the former refers dealing sociology by using postmodern epistemology, and the latter one refers analyzing postmodern times, the new developments in society sociologically. We can see the same distinction also in an article of Parker (1992), he adapted this separation to organization studies. According to him (1992, pp. $10-12$ ), postmodern organization and postmodern organization theory are different fields. The scholars studying "postmodern organization" focus on new forms of organizations in the postmodern times, but postmodern organization theorists use new theoretical perspectives to analyze organizations.

In the literature review, it has seen that there aren't many articles that combine postmodernism with public relations field. When we examine those articles, we can see the same division in the studies which combines the concept of postmodernism with public relations. Most of the authors (Holtzhausen, 2000; Holtzhausen and Voto, 2009; Toth, 2002), use postmodern epistemology to break the hardness of modern public relations. They advocate that postmodernism can open new windows for modern public relations; it can make it more democratic, participative and raise the power of the target audience. Others (Mickey, 1997; Radford, 2011; Saydam, 2013; Bitirim, 2011) take into consideration how the public relations field and implementations have changed in the postmodern era. This paper takes a stand into latter perspective, and considers postmodernity as an era. 
However, when we take postmodernity as an era, we see that there are many different thoughts about it. The years' beginning with 1970 's named differently by various thinkers. Some define this period "postmodern" and they thought this era is a break from the previous era (Lyotard, 1984; Baudrillard, 1998); some advocate this era is the follow up of the previous period and name it "late modern" (Giddens, 2005) and some call it "flexible capitalism" (Sennett, 2008). They all name it differently; however, every one of them agrees that there is a political, economic, cultural and social change after 1970's. With the change in culture, art, the lifestyle of individuals, organizations and the way of management; it is an obligation to rethink and reexamine most of the fields and concepts. One of these fields is "public relations". The most popular definition of public relations is "the management function of creating and maintaining goodwill of an organization's various publics". The main concepts which are "public", "organization" and "management" have transformed into the postmodern world.

The main claim of this article is that in the postmodern era, public relations become a mean for enchantment and it became a tool for seduction and satisfaction. It forms images, which became more important than reality, and blurs the line between reality and image. Pseudo-events turned into an essential tool for public relations since organizations need to be more visible in this era in which images turned out to be more vital than realities. Because of that reason, in this article firstly the characteristics of the postmodern era were discussed. Secondly, postmodern public relations was analyzed. Thirdly, pseudo events in the postmodern times was emphasized. Finally, an example of a pseudo-event named Pink or Black Night which was conducted by Magnum (Unilever) will be analyzed as a forms of public relations implementation in the postmodern era.

\section{The Postmodern World}

The transition from modernity to postmodernity is a very controversial issue. Some authors believe that we are still living in a modern world; however, some reject this idea and advocate mankind is living in a new period of time, which is ruled by different values called postmodernism. Featherstone (2007, pp. 3-10), emphasized this argument by indicating different sides. Some thinkers argue that it represents a break from modernity, some argue it is a continuation of modernity. Some think this term is a temporary and shallow intellectual fad; some argue that it is not just a break from artistic modernism, but also break from a whole modernism era. One can say that the basis of this discussion lies under the prefix "post". According to Best and Kellner (2000, pp. 47-48), the term "post" in the postmodern is ambiguous. On one hand, it describes non-modern. In other words, it means an active negation beyond the modern era and its theoretical and cultural practices. On the other hand, it led some critics to conceptualize postmodern as a hypermodernity, new face of modernity or postmodern development in modernity. However, according to Featherstone (2007, pp. 10) the prefix "post" clearly means a break or rupture, so postmodern is a break from the modern era.

When one tries to define postmodern era, we confront numerous definitions filled with different concepts like "loss of a sense of historical past, schizoid culture, excremental culture, replacement of reality by images, unchained signifiers" (Featherstone, 2007, pp. 11). There isn't "one" definition of postmodernism. Therefore, emphasizing postmodern writers' thoughts on this concept is very important to understand it.

Lyotard advocates that postmodernism is not a break from modernism. He said (1984, pp. 79) "it is undoubtedly a part of modern" and "postmodernism understood is not modernism at its ends, but in the nascent state and this state is constant". By that he emphasizes that it is a new step of modernism. According to him, postmodernism simply indicates a mood, or better a state of mind. It is a movement towards a postindustrial era and it is a happening within capitalism. He argues that there is a loss of meaning in this era that should not be mourned. Because it points to a replacement of narrative knowledge by plurality of language games, and universalism by localism (as cited in Featherstone, 2007, pp. 3-4).

As indicated by Jameson postmodernism is a cultural logic of late capitalism, which is the third stage of capitalism emerged after the Second World War. He (1991) advocates that culture became a meta and society turned into a consumer society in the late capitalism. This society saturated with signs and images. In this new culture, reality transformed into images, and also time fragmented into small presents. 
Baudrillard (1998) states a new social order in which the distinction between reality and appearance have erased because of the simulations in the postmodern era. Additionally, the differentiation between real needs and false needs have disappeared. Consumer goods became tools to gain privilege and prestige and consumer action has also become a necessity for individuals. Individuals feel obligated to consume, because they don't want to be excluded from society. Media determines "needs" in this era. Consumers give "yes" or "no" answers to alternatives displayed by the media because they don't have time to think which they really need. Also, postmodern era has a hyper reality characteristic. Hyper-reality eliminates the distinction among reality, fiction and imitation. He saw public relations as a tool to dissolve real and fiction in postmodernism.

To summarize, one can say that the era we are living in, is a "bouncing" moment as Ylldiz (2013b) said. The change in politics, economics, and society required the redefinition of many fields, concept and profession. We can say that these changes also influence public relations field.

\section{Thinking of PR in The Postmodern World}

Public relations have many different definitions. In 1970's Harlow studied public relations definitions. He found 470 public relations definitions and built a description from them. As indicated by him (1976) public relations is:

"A distinctive management function which helps establish and maintain mutual lines of communication, understanding, acceptance and cooperation between an organization and its publics; involves the management of problems or issues; helps management to keep informed on and responsive to public opinion; defines and emphasizes the responsibility of management to serve the public interest; helps management keep abreast of and effectively utilize change, serving as an early warning system to help anticipate trends; and uses research and sound and ethical communication techniques as its principal tools."

From 1970's one can say that more definitions were made for public relations. Hutton (1999, pp. 201) re- viewed public relations definitions in textbooks and academic literature and he found that most common definitional components appear to be "management", "organization" and "publics". He said practitioner definitions as well tend to concentrate on "management", "organization" and "publics". These concepts transformed in the postmodern era. Publics fragmented and individualism rose; new organization structures occurred, new management styles emerged in postmodernism. When the concepts in public relations definition changed, then the implications and practices have also transformed.

Modernity accepts the understanding of "progress" and because of this reason when we look at public relations within the frame of modernity, public relations progress steadily. It inverted in a linear manner and always for the better. The dominant perspective is Grunig and Hunt's four models in public relations. After that, "Excellent Public Relations"1 became the dominant paradigm. With the emergence of the Internet, academicians began to discuss the practicality of "dialogical public relations"2. US hegemony has effected textbooks and history writing in the field of public relations. According to this perspective, public relations accepted as a progressive, ethically developing field. This understanding has affected the global look on public relations (L’etang, 2013, pp. 804-807).

1 This theory was emerged as a result of International Business Communication Association's research project. In this project, they searched the features that make public relations effectiveness and implications excellent. According to this theory, excellent public relations must have following characteristics: communication value, contribution to strategic organizational functions, management role, two-way symmetrical model, public relations professionals who have the skills to implement this model, strong organization culture, multicultural organization structure (Grunig, Grunig and Dozier, 2003).

2 Pearson is the first one who used "dialogue" in public relations. $\mathrm{He}$ argued that dialogue is a very important tool for public relations' ethic (Kent and Taylor, 2002, pp. 21). Some writers claim that, public relations shift towards techniques based on dialogue. For instance Mersham, Theunissen and Pearl, advocate that public relations will be about dialogue instead of traditional one-way monologues in the future (Theunissen and Noordin, 2012, pp. 5). According to Taylor and Kent (2002, pp. 23), there is a shift in public relations from symmetry to dialogue. Earlier the emphasis was on managing communication, yet now it is on "communication as a mean to negotiate relations". Now building and maintaining relationships is important for public relations. However, practicable of dialogue in public relations is a very controversial issue. According to Theunissen and Noordin (2012, pp. 6), dialogue is a philosophical and abstract concept. It is very hard to reflect an abstract concept to the implementation. Also, it is very debatable how appropriate is dialogue for organizations who want to influence and control their environment. 
However, one can say that there isn't a linear progression in the field of public relations. It is seen that many organizations use Grunig and Hunt's four models at the same time or pick appropriate model for the moment, some organizations develop new models $^{3}$ which is suitable for them. Consequently, we can't talk about a public relations model suitable for each organization or each country. However, we can say that characteristic of different periods, influences public relations applications. Each period or era has distinctive characteristics with its own mindset and paradigms (Bitirim, 2011, pp.120). These characteristics affect and change all fields.

We can say that in the postmodern era, public relations works as an "enchantment tool". According to Weber, modernity disenchanted the world because of the rationalization. "His work is characterized by pessimism and a weary acknowledgment of what Jedi of Star Wars might call the 'Dark Side' of the Force of modernity (Jenkins, 2000, pp. 12). The concept "enchantment" was borrowed from Ritzer. Ritzer (2011) explains enchantment and disenchantment by using theories of Marx and Weber. According to Ritzer (2011) modernity disenchanted the enchantment in consumption relations because of rationalization. And because of that reason, there was a need for new enchantment tools. These tools emerged in the postmodern era. Ritzer states that these tools are chain stores, shopping malls, discount stores, as well as advertising and public relations. In this context, public relations manipulate individuals to purchase by recreating warmness of face to face relations which lost in the modernity as Weber explains by the "disenchantment" concept. "Weber indicates that 'consumption relations' serve enchanted world. What disenchants the world is a consumption relations defined as 'polar night', 'icy darkness' and 'hardness'. Therefore, there is a need for tools to realize re-enchantment and these are the sum of marketing and public relations exercises" (Yildız, 2013a, pp.126).

3 For example, some organizations in South Africa use "Ubun tu". It is a literal translation for collective personhood and collective morality. It is used to build relationships through building a spirit of harmony and reconciliation. In this model public relations departments are responsible to organize workshops and forums to from harmony in workplace. Also, it functions as a strong proponent of the emancipation and liberation of marginalized internal and external publics (Holtzhausen, Peterson and Tindall, 2009).
Although Weber was not a cynic, his work is characterized by pessimism and a weary acknowledgment of what the Jedi of Star Wars might call the 'Dark Side' of the Force of modernity. For Weber the disenchantment of the world lay right at the heart of modernity.

One can say that public relations also enchant people by promising happiness, satisfaction and prosperity. According to Ylldiz (2013a, pp. 124), these commitments are impossible to reach in postmodern society. However, dazzling slogans about these commitments are still standing. People could believe that relating with a specific organization could bring happiness, satisfaction or prosperity to them.

According to Baudrillard (1998, pp. 168), the aim all apparatuses like advertising and public relations is both to care and to satisfy, on the one hand, and surreptitiously to gain by enticement and abduction on the other. The average consumer is always subjected to this two-pronged undertaking. In this manner, in postmodern era where images took place of reality, public relations become one of the most effective powers of organization. In other words, it could serve as a tool to blur the lines between reality and the images organizations create for their benefits.

In the postmodern world, everything has become symbols and icons, symbols took place of everything. These images and symbols perceived as real. For that reason, because public relations pumps symbolic images, it became on the most popular professions in this era. Postmodernism accepts that truth is constructed and public relations is also considered as a tool that constructs reality. (Bitirim, 2011, pp. 134-139). In this manner, we can approach public relations as a tool to promote new identities for people. By saying that, I mean public relations relates some images (like cool, stylish, reliable, rich etc.) with organizations. When people consume products from this specific organization, they can think that these symbols are transferred to their identities.

\section{"Pseudo-Event" as a Form of PR in The Postmodern World}

With the development in communication technologies, individuals are exposed to millions of messages every day. Consider a day of an average person: When she is going to work, she sees a beautiful girl on a bill- 
board telling her to buy a perfume to be desirable. Then she looks at her phone to call a friend, she sees a promotion message coming from a known brand. When she is listening radio, she hears dozens of advertisements. She checks her Facebook, sends a tweet, posts a photo on Instagram... While doing all of them, she sees, listens and watches millions of messages coming from different sources and telling what is best for her.

Therefore, one can say that, postmodern individual is confused. According to Radford (2011, pp. 60), "the postmodern subjects find themselves perpetually bombarded, given the chance, by 30 -second sound bites photo ops, and 140 character tweets...Narrative is replaced by flow, connection is replaced by disconnection, and the sequence is replaced by randomness". So, media turned into an important tool to convey messages in the postmodern world. According to Baudrillard (1998), media is very effective in shaping individuals' "needs" and the way how they are thinking. They choose among the alternatives that media shows.

In a world like that, public relations practitioners should be more creative to make their organization visible. According to Radford (2011, pp. 60), "in the postmodern condition, the messages created and distributed by a PR practitioner are inevitably received and interpreted in the context of a broad array of competing messages, perspectives, ideologies, viewpoints, information sources and even other PR practitioners representing competing interests". In other words, in the postmodern world PR professional should work more to find more interesting ways to convey their messages to the target group. They need to compete with other messages.

Therefore, pseudo-events became more important for PR practitioners in the postmodern world. The terms "pseudo-event" or "media event" refer to the phenomenon that many events are created with the sole aim of getting media coverage, or rather that events are staged in a way that lend itself to media coverage (Scherer, 2008, pp. 2908). According to Boorstin, who created this concept, pseudo-events have some characteristics (1992, pp. 10-11): First of all it is not spontaneous; it comes about because someone has planned, planted, or incited it. Most of them are basically strategic communication and public relati- on exercises. Secondly, it is planted primarily for the immediate purpose of being reported or reproduced. And its success is measured by how widely it is reported. Because of that reason the question "Is it real?" is less important than "Is it newsworthy?" Thirdly, its relation to the underlying reality of the situation is ambiguous. And Scherer (2008, pp. 2908) said that it is usually intended to be self-fulfilling prophecy. These events have to be designed according to media criteria. If the event itself is not newsworthy, it has to be artificially enhanced to make it more interesting for the media. And usually it is done by involving celebrities or adding dramatic effects to the event.

Robinson (2006) advocates that today' public relations developed into an active part of the firms' promotional activities like event sponsorship, stunt marketing, charitable activities and placement. By saying stunt marketing, he means "a pseudo-event for the sole purpose of attracting press coverage". According to Robinson (2006, pp. 253), this activity is limited in the scope in that they do not provide an opportunity to convey complex information about product benefits. Because of that they are best suited to the early part of product life cycle.

There are lots of examples of pseudo-events. Boorstin (1992, pp. 10) gives a public relations implementation about a hotel whose work doesn't go with a swing. Hotel asked a PR practitioner what to do. And this practitioner stages an event to celebrate the $10^{\text {th }}$ anniversary of the hotel and he invited celebrities. Robinson (2006, pp. 252) gives another example about Nathan's Coney Island Hot Dogs. This firm stages a hot dog eating contest that achieves international media coverage every year and gets media's attention.

We can't say the pseudo-event is indigenous to the postmodern era. However, in the postmodern era, with the blurring lines between images and reality, one can say that it became more important for PR practitioners. With pseudo-events, organizations become more visible in a world where different images compete. In addition to that, an organization can spread ideas about their products and strengthen their images by using pseudo-events.

Approximately 25 years passed after Boorstin defined pseudo-events. He said pseudo-events aim media coverage and he emphasized the power of television. In 
2000 's, we can add the power of internet to "media coverage". In the postmodern world, internet coverage (twitter, facebook, instagram, etc.) is equally or maybe more important than television, newspaper and radio. Therefore, by planning pseudo-events, organizations also try to have "likes", "comments" and be "trending topic" in the internet world. And interactivity became an important way to be visible.

Best and Kellner (2016) state that we move to another stage of the "spectacle". Previously, people sitting in front of the screen are passive. Therefore, the subject was dominated by the object. In other words, spectacle tools were control mechanisms that keep people passive. However, the subjects are now more active because the computer, multimedia and virtual reality tools are more interactive in the new stage of spectacle. But they say we have to be careful, when we talk about interactivity. Interactivity's effect on democratization and empowerment of the subject is very controversial. In addition to that, with interactivity subject have a more active role in spectacle. Interactive tools include subject into spectacle in many different ways. So, we can say that interactive technology opens a way to a deeper connection with spectacle by seducing audience.

Public relations tools and events produce symbols to communicate with publics. Public relations form messages which aren't reflections of reality, but a creation of thought. It is called "hyper-reality". Public relations produces images that become more important than reality (Bitirim, 2011, pp. 137-138). With these explanations, ethical discussions become more important than before. We have to discuss public relations "ethics" in the postmodern era critically with considering the increasing number of pseudo-events and the exaggerated power of internet (about forming "dialogue" between an organization and its publics).

\section{Case Study: Magnum Pink or Black Night}

In this article, Magnum's Pink or Black campaign is analyzed as a case study. To analyze this campaign, an internet research was made, newspaper articles were examined, new about this campaign on television was researched, and the live broadcast of the event was analyzed by using descriptive analysis.
Magnum is a brand of Unilever ${ }^{4}$, which is a global company active in 97 countries. It put on the market in 1989 firstly in Germany. It was the first ice-cream targeted adults. Magnum's is distinctive; luxury branding aim females, 15-35 years old ("Magnum's Multimedia", 2015). In 1994, it was put market in Turkey, and in a short time it become very successful. Magnum made significant blockbuster events and campaigns since it has launched in Turkey. Pink or Black campaign is one of them.

Magnum made Pink or Black campaign in 2013. Magnum launched two new ice-creams: Magnum Pink Raspberry and Magnum Black Espresso. In this campaign, Magnum emphasizes two different moods with these two different tastes. In their campaign website (www.pinkorblack.mymagnum.com), they said "we bring you two very different, two different but equally delicious taste sensations, perfectly tailored for different moments. Depending on your mode, choose between fruity playfulness and rich sophistication". As it is seen, Magnum says each woman has two different moods and we have different products suitable for these moods. The slogan of this campaign is "Different ice-creams for different moments" and "What mood are you in today?".

In the worldwide campaign, firstly Magnum created a poll on Twitter asking "what mood" women are in to raise awareness for new products. After that the campaign culminated in asking people to vote to light up a range of iconic landmarks either pink or black (TMW, nd.). The aim is "to activate the Magnum PinkeBlack campaign in digital and social channels and support the PR campaign by driving excitement and sales around the release of two ice cream flavors" (Byran, n.d.). This campaign was made in big cities like Paris, London, Brussels, Amsterdam, Lisbon, Hamburg, Vienna and Rome before it was made in Istanbul.

In Turkey Pink or Black Night was a successful event for Magnum. Magnum explains this campaign as fol-

4 Unilever is one of the biggest fast moving consumer goods (FMCG) companies. Unilever who constantly increase its efficiency in global market, made its first investment in Turkey, in 1952. Its portfolio ranges from nutritionally balanced foods to indulgent ice creams, affordable soaps, luxurious shampoos and everyday care products (www.unilever.com). 
lowing (Trdpid, 2014): Magnum represents energetic and sophisticated faces of women. Magnum's new tastes should cause more excitement before last year, and it should transform to huge "news" that was spoken about. Magnum should create a unique experience that shows its sophisticated and energetic sides of the brand. People can choose Magnum Pink or Magnum Black regarding to their mood, so why they can't they choose İstanbul's color?

To realize this, Magnum Turkey started a poll on Twitter asking should İstanbul be pink or black. After twitter vote, pink won with the $\% 67$ of the votes. On $22^{\text {nd }}$ of May, 2013 İstanbul witnessed the city turning into pink. Sait Paşa Mansion, Haydarpaşa train station, Galata Tower, Kabataş High School, Beylerbeyi Palace, Maiden's Tower, Rumelian Castle and Bosporus Bridge were lightened pink.

This public relations event is very successful. This pseudo-event has featured on television for 5 hours 43 minutes as "news", published in 70 different newspapers. 139 different "news" made about this event on digital channels and 100.000 people watched this event live on twitter. After this event, there in a \%970 percent increase in the conversation about the brand in social media. This event reached more than 25 million people and 1.2 million dollars PR value was obtained (Trdpid, 2014). It is the first time that Twitter writes a success story of a Turkish brand (Öner, 2013).

Based on Boorstin's criteria, we can say that Pink or Black Night is a pseudo-event. It is a planned event, not spontaneous. Also, this event was realized primarily for the purpose of media coverage to increase awareness about both the new products of Magnum, and the brand itself. Thirdly, it is not about reality. They lightened some iconic landmarks in Istanbul for only one night. In addition to that, people choose the color regarding women's moods, which were produced by Magnum. They create a type of women who is sexy, sophisticated, clever, hard-working but always well-groomed. This not a real woman, they produce a hyper-real women for Magnum who is very desirable. Finally, it is a self-filling prophecy. Also, they used a world-famous celebrity, Orlando Bloom to attract media's attention. They add dramatic effects like a fashion show and after party.
The event was broadcasted live on CNN Türk and Twitter account of Magnum. Live broadcast realized in Esma Sultan Mansion, Tülin Şahin and Nefise Karatay who are famous models presented the show. Famous people from business and art world attended to the event. There was a "pink carpet" and guests entered the mansion after walking on it. Orlando Bloom was the face of this campaign and was the star of the event. Tülin Şahin interviewed Orlando Bloom on the live program. Bloom explained the Magnum project on his interview: "It is more about two different moods of women. On one hand pink and sexy, on the other hand black and sophisticated." When the Şahin asked him which one he prefers, he said both of them.

Karatay was in front of Maiden Tower. She interviewed with Carla Moure who is an Italian model. She was wearing a "lighted dress" designed for this event. It was a unique dress that can change its color. After the voting on Twitter, her dress turned into pink on the live event.

As a part of this night, Magnum made a fashion show with Özgür Masur, who is a very well-known designer in Turkey. Karatay also made an interview with him on the live show. He described his collection. The collection includes 14 dresses ( 7 pink and 7 black). He also talked about pink and black women. Black woman is rebellious, powerful, smooth and cool and pink woman is present-minded. He also added that "Magnum woman knows pleasure".

Mustafa Seçkin (Unilever Board Member Responsible from The Food and Marketing) explained the campaign on the show. He emphasized Magnum is an unusual brand, and it stands in a different place in their entire portfolio. He said this brand is about maximizing pleasure, so they are trying to reflect this idea in all of their work. He reminds that Magnum has worked with lots of starts like Elizabeth Hurley, Josh Holloway, Benito Del Toro and Kıvanç Tatlıtuğ before. Therefore, it is a brand of stars, and star of icecreams.

Leyal Eskim Yilmaz (Algida Marketing Director) also gave an interview. She talked about Magnum Pink and Black and said these products have stories beyond themselves: Pink is a more sincere, cheerful and entertaining mood, on the other hand Black repre- 
sents more glamorous, flashy and sophisticated moments. We all pass one mode to another...Magnum is a brand of pleasure because of that it includes everything about pleasure. Also, she talked about two presents, which will be given after the show: 2 Porsche's (one of them is pink and the other is black).

After the interviews, in the live broadcast we see Istanbul becoming "pink" in the light of the Twitter voting. The dress of Moure turned into "pink". After the live show, a fashion show designed by Özgür Masur and the cute circuit ${ }^{5}$ has started. It also broadcasted lively on CNN Türk and Twitter.

This pseudo-event organized by Magnum is a very successful public relations event. This event created simulations in many ways. According to Baudrillard (2014, pp. 14-15), simulation is a not an imitation or a parody, it is a new form of reality in which symbols put display instead of the original. In this case, people choose the color of Istanbul with a Twitter poll, so they include their target group directly to the event. We can say that they create a simulation of "dialogue" and "participation". Voters choose the color pink and Istanbul lightened in pink. However, it could be black; Magnum doesn't care about the color. The only aim of the company was to get attention of media and its publics. Subsequently, we can say that internet was used to widen the effect of the event not to form a permanent dialogue and understanding between the brand and its publics.

In addition to that, they created a hyper-real Magnum woman. According to Batı (2015, pp. 111-112), the reality shaped by mass media became more real than the physical reality. With the production of images, the line between real and hyper-real was blurred. In this case the hyper-real Magnum woman is either sophisticated or energetic. She is always beautiful, chic and well-groomed. She is clever and intellectual.

5 Cutecircuit presents a new Haute Couture collection: the Pink\& Black Collection The dresses are designed by Francesca Rosella. This collection is presented in a series of fashion events organised worldwide by Magnum ("About cutecurcuit", 2016).
Therefore, she can get whatever she wants, even if it is Orlando Bloom. This message promoted on both in the event with the interviews and the advertisement Orlando Bloom acted. Magnum transferred this kind of values and images by means of advertisements and the pseudo-event. In a world where images became more important than reality, it means that after the events like that Magnum isn't selling just an ice cream. It sells prestige, status, and values like sophistication, energy, beauty and pleasure. Products gain new meanings outside of their usage area and became simulations. The symbols of emotions, needs, moods, warm interest, success or advantage were attributed to products (Funk, 2013, pp. 29-30).

\section{Conclusion}

Pink or Black Night and the whole campaign looks like "press agentry" model. It created simulations in order to get attention, and increase awareness about its products. According to Koç (2006, pp. 333), increasingly companies place a strong emphasis on "press agentry". It is about creating newsworthy stories and event to attract media attention and gain public notice, also cultivate a reputation which attracts media and public attention. So, one can say that pseudoevents are a part of "press agentry". They have similar aims.

In Pink or Black campaign held in Turkey, they also included public into the campaign. Public (the voters of the pink or black poll) became a part of the story that Magnum created. Magnum asked people to create this pseudo-event. By that people was getting drawn into this constructed story. We can say that this is a postmodern situation and it shows us there is not a linear development in public relations. Internet and "dialogue" was used to create a pseudo-event.

This article only analyzed one case to build an insight about how public relations transform in postmodern times. To develop a broad understanding about PR field in postmodern world, there should be further studies both using qualitative and quantitative methods. 


\section{References}

About Cutecircuit. (2016, May 15). Retrieved from http://cutecircuit.com/about-cutecircuit/

Batı, U. (2015). Tüketim Davranışları. İstanbul: Alfa

Baudrillard, J. (1998). The Consumer Society. London: Sage.

Baudrillard, J. (2014). Simülakrlar ve Simülasyon. O. Adanır (Trans.). Ankara: Doğu Batı Yayınları.

Bauman, Z. (1992). Mortality, Immortality and Other Life Strategies. Cambridge: Polity Press.

Bauman, Z. (1998). Sociology and Postmodernity. The Sociological Review 34(4): 790-813.

Best, S. and Kellner, D. (2000). Postmodern Teori: Eleştrirel Soruşturmalar. M. Küçük (Trans.). İstanbul: Ayrıntı Yayınları.

Best, S. and Kellner, D. (2016). Debord and Postmodern Turn: New Stages of the Spectacle. Retrieved from https://pages.gseis.ucla.edu/faculty/kellner/Illumina\%20Folder/kell17.htm

Bitirim, S.(2011) Postmodernizm Perspektifinden Halkla İlişskilerde Etkinlikler\&İmajlar: Halkla İlişkiler Etiğinin Değerlendirilmesi. In S. Becerikli (eds.) Halkla İlişkiler ve Reklamın Anatomisi. Ankara: Ütopya.

Boorstin, D. J. (1992). The Image: A Guide to PseudoEvents in America. New York: Vintage Books.

Bryan, K. (n.d.) Magnum-Pink\&Black [Website]. Retrieved from http://www.tmwunlimited.com/ourwork/case-study-magnum-pink-black

Different Ice-Creams for Different Moments. (n.d.) Retrieved from http://pinkandblack.mymagnum. com/en-gb/

Dühring, L. (2015). Lost in Translation? On the disciplinary status of public relations. Public Relations Inquiry, 4(1), 5-23.
Featherstone, M. (2007). Consumer Culture and Postmodernism. London: Sage.

Funk, R. (2013). Ben ve Biz: Postmodern İnsanin Psikanalizi. Ç. Tanyeri (Trans.). İstanbul: YKY.

Gower, K. (2006). Public Relations Research at the Crossroads. Journal of Public Relations Research, 18(2), 177-190.

Grunig, L., Grunig, J. \& Dozier, D.M. (2003). Excellent Public Relations and Effective Organizations. London: Routledge.

Harlow, R.F. (1976). Building a Public Relations Definition. Public Relations Review , 2(4), 34-42.

Hınçal, T. (2011) Şizofreni, Halkla İlişkiler ve Bir Yapısöküm Uygulaması Olarak Mavi At Kafe. In S. Becerikli (eds.) Halkla İlişkiler ve Reklamin Anatomisi. Ankara: Ütopya.

Holtzhausen, D. (2000). Postmodern Values in Public Relations. Journal of Public Relations Research, 12(1), 93-114.

Holtzhausen, D., Voto, R. (2009). Resistance From The Margins: The Postmodern Public Relations Practitioner as Organizational Activist. Journal of Public Relations Research, 14(1), 57-84.

Holtzhausen, D., Peterson, B.K. \& Tindall, T.J. (2009). Exploding the Myth of The Symmetrical/Asymmetrical Dichotomy: Public Relations Models in the New South Africa. Journal of Public Relations Research, 15(4), 305-341.

Hutton, J.G. (1999). The Definition, Dimensions, and Domain of Public Relations. Public Relations Review, 25 (2), 199-214.

Jameson, F. (1991). The Cultural Logic of Late Capitalism. Durham: Duke University Press.

Jenkins, R. (2000). Disenchantment, Enchantment and Re-Enchantment: Max Weber At The Millenium. Max Weber Studies, 1(1), 11-32. 
Kent, M., Taylor, M. (2002). Toward a Dialogic Theory of Public Relations. Public Relations Review, 28, 21-37.

Koç, E. (2006). Order three advertisements and get one news story free: Public relations ethics practices of Turkish and international companies in Turkey. Public Relations Review, 32, 331-340.

L'Etang, J. (2013). Public Relations: A Discipline in Transformation. Sociology Compass, 7(10), 799817.

Magnum's Multimedia Campaign is Turning Summer Pink\&Black. (2015, Mays 29). Retrieved from http://www.mycleveragency.com/blog/2015/05/ magnums-multimedia-campaign-is-turningsummer-pink-black/

Mickey, T. (1997). A Postmodern View of Public Relations: Sign and Reality. Public Relations Review, 23(3), 271-284.

Lyotard, J.F. (1984). The Postmodern Condition. G. Bennington and B. Massumi (Trans.). Manchester: Manchester University Press.

Okay, A., Okay, A. (2011). Halkla İlişkiler: Kavram, Strateji ve Uygulamaları. İstanbul: Der Yayınları.

Öner, D. (2013). Magnum Twitter'in en Başarıll Kampanyalar Arasinda [Magazine Article]. Retrieved from http://www.campaigntr. com/2013/09/23/54990/magnum-twitterin-enbasarili-kampanyalari-arasinda/

Özdemir, P., Yamanoğlu, M. (2009). Disiplinlerarası Bir Alan Olarak Halkla İlişkiler: Türkiye'deki Akademik Çalışmalar Üzerine Niteliksel Bir İnceleme. F. Keskin \& P. Özdemir (eds.), Halkla İlişkiler Üzerine. Ankara: Dipnot Yayınları.

Parker, M. (1992). Post-Modern Organizations or Postmodern Organization Theory. Organization Studies, 13(1), 1-17.

Radford, G. (2011). Public Relations in a Postmodern World. Public Relations Inquiry, 1(1), 49-67.
Ritzer, G. (1996). Postmodern Social Theory. New York: The Mcgraw-Hill

Ritzer, G. (2011). Büyüsü Bozulmuş Dünyayı Büyülemek.S.S. Kaya (trans.). İstanbul: Ayrıntı.

Robinson, D. (2006). Public Relations Comes of Age. Business Horizons , 49, 247-256.

Saydam, D. (2013). İletişim Ajanslarında Medya İlişkileri Yönetiminde Paradigma Değiş̧ikliği: Postmodern Halkla İlişkiler (Unpublished doctoral dissertation thesis).Marmara Üniversitesi Sosyal Bilimler Enstitüsü, İstanbul.

Scherer, H. (2008). Media Events and Pseudo-Events. W. Donsbach (eds.). The Encyclopedia of Communication .Singapore: Blackwell Publishing.

Sennett, R. (2008). Karakter Aşınması. İstanbul: Ayrintı Yayınları.

Theunissen, P., Noordin, W.N. (2012). Revisiting the concept dialogue in public Relations. Public Relations Review, 38, 5-13.

TMW Unlimited. (n.d.) Retrieved from http://www. creativebrief.com/agency/work/22431/6913/ magnum--digital-social-media-pink--black--bytmw-unlimited

Trdpid. (2014, September 1). 6. DP Ödülleri (2013) Magnum İstanbul PinkeBlack Night [Video file]. Retrieved from https://www.youtube.com/ watch? $=$ nfU5b9t6QZ8

Toth, E. (2002). Postmodernism for modernist public relations: the cash value and application of critical research in public relations. Public Relations Review, 28, 243-250.

Yıldız, N., (2013a). Aş̧ Yüzyıl Bitti: Așk'ta, İş'te, Siyaset'te Yeni Zamanlar. İstanbul: Doğan Kitap.

Yıldız, N., (2013b). Kaos, Kriz ve Halkla İlişkileri Yeniden Düşünmek. M. Aktaş, P. Özdemir (eds.). Halkla İlişkilerin Kazancı. Ankara: DeKi Yayınları. 